pp. 376-387

\title{
An Appraisal of the Impact of International Trade on Economic Growth of India- through the ARDL Approach
}

Submitted 19/02/20, 1st revision 11/03/20, 2nd revision 28/03/20, accepted 25/04/20

Abstract:

Radha Raghuramapatruni ${ }^{1}$, Reddy V. Surya Chaitanya ${ }^{2}$

Purpose: The study examines the impact of international trade on economic growth of India by using the Autoregressive Distributive Lag Model (ARDL) technique. The study further adopts Trade Openness Index to analyze the growing integration of India's external trade with the outside world.

Design/Methodology/Approach: The study employs the Augmented Dickey Fuller (ADF) Test for unit root and Autoregressive Distributive Lag Model (ARDL) cointegration approach which entails the Wald Test, Long run OLS estimation test, Error Correction and short Run relationship estimation test, as well as the short run Causality test. The data on the variables of model and Trade Openness Indicator were sourced from the various data sources of the Handbook of Statistics on the Indian Economy and the UNCTAD, World Bank Databases. The Data for the index and the model is collected and analysed for the period of 1991 to 2017.

Findings: The analysis of the Augmented Dickey fuller (ADF) test for unit root shows that the series were of different order, I(I) and I(O), hence the Autoregressive Distributive Lag Model (ARDL) co-integration technique was employed by the study. The long run relationship of the underlying variables is detected through the F-statistic (Wald test) which shows that the series are co-integrated. Long run relationship estimates presents a positive and significant relationship between exports and domestic investment with GDP. The analysis presents that the relationship between the variables imports and exchange rate with GDP was found to be negative, but statistically insignificant and the speed of adjustment term (Error Correction Term) was also found to be significant. Short run causality result reveals the presence of short run causality between exports, domestic investment and exchange rate to GDP.

Practical Implications: The paper concludes a positive relationship between international trade and economic growth and supports the ideology of mercantilism to encourage exports through trade promotion and increased participation of India in the world markets.

Originality/Value: The authors conclude a positive impact of international trade on India's economic growth and long run relationship estimates present a positive and significant relationship between exports and domestic investment with GDP. Further analysis on implications on bilateral treaties and tariffs would add value to the current study.

Keywords: ARDL Approach, Economic Growth, India's Trade, Augmented Dickey Fuller.

JEL Classification: $C 1, C 4, F 1, F 4$.

Paper type: Research article.

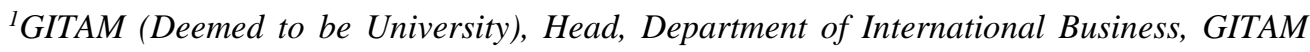
Institute of Management, e-mail: $\underline{\text { dr.radhapatnaik@gmail.com }}$

${ }^{2}$ GITAM (Deemed to be University), Research Scholar, GITAM Institute of Management, e-mail: suryame2015@gmail.com 


\section{Introduction}

There are two versions regarding the role of foreign trade in economic development and the type of trade strategy, which has to be followed by the countries for their development. The first version, which believes that the "trade as an engine of growth" (Nurske, 1970) is the strategy of export-led growth also called as outward-oriented strategy. The second treats "trade as hand maiden of growth" (Kravis, 1970), is inward-oriented strategy or the strategy of import substitution. There has been extensive discussion in the literature on their relative merits.

Historical validation has revealed that countries with largest volumes of international trade and greater integration with outside world tend to be more productive than countries which are only dependant on domestic market (Atouebi et al., 2012). Also the historical evidence of the growth trajectory of Great Britan and the experiences of Germany, Italy and Japan during the 1950s points to the positive association of exports and economic growth (Balasa, 1970). Canada and Switzerland during 1900, 1913 can be cited as the other examples of export led growth. In addition the case of Brazil (coffee), Bolivia (tin), China (cocoa) and Iraq (oil) may be cited as examples where as higher level of export trade activity had benefited the domestic economy though temporarily.

The recent performance of East Asian economies during the "East Asian Miracle Phase" and the growth trajectories of New Asian Tigers India and China are some of the best cases to study the impact of international trade on economic growth. The explicit goals of the 1991 economic policy reforms in India after 1991 with respect to the external sector were to create a major shift in the momentum of export growth in the country and to attract larger inflows of foreign capital in the form of export oriented FDI (Jayathi, 2006). These economic policy reforms undertaken at the beginning of the 1990s have helped the country move from its Hindu rate of growth to an average Gross Domestic Growth rate of 6.5 percent during the last decade. Witnessing the rapid economic growth, India has now become one of the emerging market economies of Asia in terms of trade. It is on this note that the study intends to analyze the relationship between international trade and economic growth of India with the help of Autoregressive Distributive Lag Model (ARDL) model.

\section{Literature Review}

The role of foreign trade in economic development needs no emphasis. Trade can stimulate growth, if exports tend to increase faster than imports or be a brake on growth if imports tend to increase faster than exports, except in case of higher proportion of capital goods imports (Samuelson, 2001). Maizel (1968) studied the relation between industrialization and international trade. He examined both imports and exports in this connection. His findings suggest that any substantial variation in the exports resulting from industrialization would affect the level of imports indirectly via the effect on exports. He observed that the import content will decline in a 
developing economy, after reaching a matured stage of industrialization. Balassa (1978) investigated the correlation between export and economic growth for a group of 11 developing countries for the period of $1960-73$. The results of correlation and regression analysis show that the export growth favourably effected the rate of economic growth. Tyler (1979) extended Balassa's work by using bivariate model to test a cross-section of 55 countries and found that there is a significant positive association between growth and total exports. He found that export performance was important in explaining the inter-country variation in G.D.P. growth rates during 1960 -71 periods.

Atoyebi et al. (2010) viewed that that there exists a positive relationship between international trade and economic growth of the country, in that both international trade volume and trade structure towards high technology exports result in a positively effect on the economy. Giaruzazmi (2011) carried out a study of the Impact of Trade Liberalization on Economic Performance of Members of OIC which liberalized their economies since 1970's. His findings posits that although the effect differs from country to country, but on the average, trade liberalization has improved the countries' GDP per capita in the medium term, but the ratio of exports, imports and trade over GDP did not improve after trade liberalization.

Azees et al. (2014) opined that international trade has a significant and positive impact on economic growth of the country. The results of the study present a positive relationship between imports, exports and openness on the economy. Ahmad (2018) studied the impact of international trade on economic growth in Bangladesh and observed the impact of variables of export and import on GDP. His study observed that international trade has a significant positive impact on economic growth in Bangladesh and international trade is strongly positively correlated with economic growth.

\subsection{Studies on Economic Growth and International Trade of India}

The general macro theories observe that international trade accelerates economic growth of an economy but the negative effects needs to be managed by sound macroeconomic policy implementation. Panchmukhi's (1978) study attempts to identify and measure the different components of trade policy system in India. The main purpose of the study is the quantitative analysis of the issues related to trade policy. He emphasized the importance of trade policies as determinant of trade patterns and discussed some selected aspects of the trade policy system elaborately, such as effects of trade policy on various aspects of domestic economic activities, conflicts between the trade policies and the objectives of planning and determinants of trade behavior. The question of relative importance of the different determinants of trade flows such as factor endowments, factor proportions, technology factor, trade policies were also examined. The import behavior of the Indian economy during the period 1950 - 70 was studied by examining the trade strategy affects the domestic relative prices. Jayati (2006) in her paper posited that Trade Liberalization in India 
were strategized with a view to creating major shift in the momentum of export growth, and to attract large inflows of foreign capital, but these objectives were not achieved. Rather, it reduced manufacturing investment due to greater threat of import penetration.

Shreesh and Kishore (2012) examined the impact of international liberalization on the Indian economy, using the Solow's model as a basis of analysis. Their findings point to the fact that international trade and openness of the economy increased the overall level of output, leading to a faster economic growth. UNCTAD's (2013) report observes that international trade increases the income and employment of the economy, but the gains have not trickled down to the poor. By observing the above studies the current paper intends to analyze the relationship between international trade and economic growth of India with the help of Autoregressive Distributive Lag Model (ARDL) model.

\section{India's Trade Openness}

The year 1991 has been a critical period for the Indian economy with huge burden of Balance of Payments deficit situation and current account deficit along with a fall in almost all the macro variables of the country determining growth and development. The study observes the performance of India's Trade Openness Indicator. The Trade Openness Index is an economic metric calculated as the ratio of country's total trade, the sum of exports plus imports, to the country's gross domestic product. The larger the ratio, the more the country is exposed to international trade.

The exports and imports growth trend of India is presented in Figure 1. The growth trend in exports and imports continued except for a few years, the year 2009 again saw a negative phase owing to US subprime crisis and for the years 2015 and 2016 owing to huge inflationary trend in the international market for oil and gold.

Figure 1. India's Growth rate of Exports, Imports \& GDP

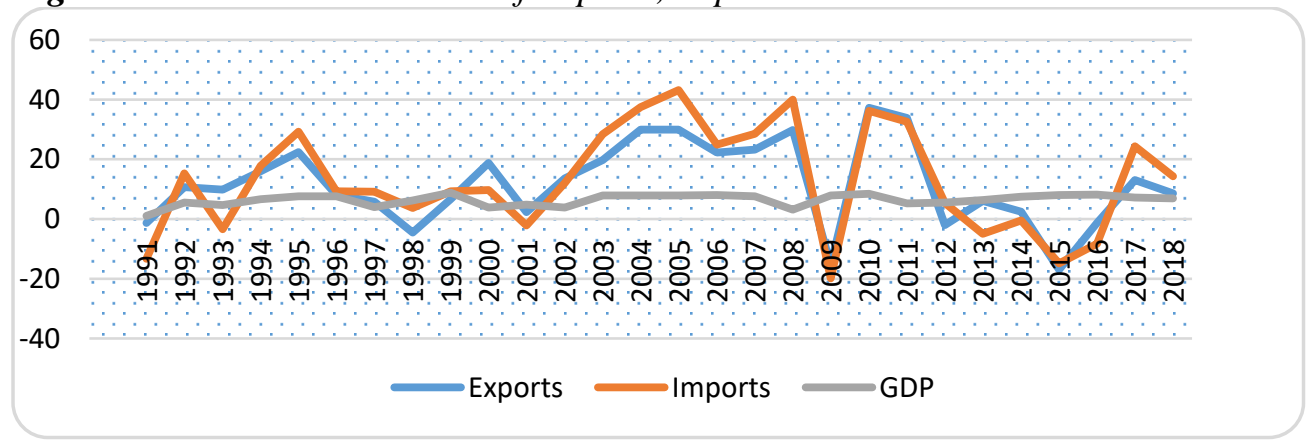

Source: Authors' Compilation of data from unctad.org

The East Asian Economies were the main beneficiaries of globalization during the post-war period as they had adopted the export-oriented economic strategies and were 
able to capture the new markets created by rapidly expanding imports of manufactured goods by the developed countries. Indian economy owing to the experience of many world economies including China and its East Asian neighbours, integrated its economy with the world economies with the policy reforms of 1991. As a result its trade openness indicators gradually improved (Figure 2). The average TOI indicator for India is at 31.012 which is less when compared with the other Asian partners. For the initial period the TOI indicator is at 19.701 and there was a gradually increase till the year 2008 which is at 42.142 and their there was a significant increase by the year 2017 which is at 30.378, except for the years 2014 (31.622) and 2015 (31.622). The gradual increase in the integration of the economy is a result of series of policy implementations trade liberalization measures taken up to liberalize the economy, the country could be seen moving up the ease of doing business index to $77^{\text {th }}$ position in the year 2019 .

Figure 2. India's Trade Openness Index

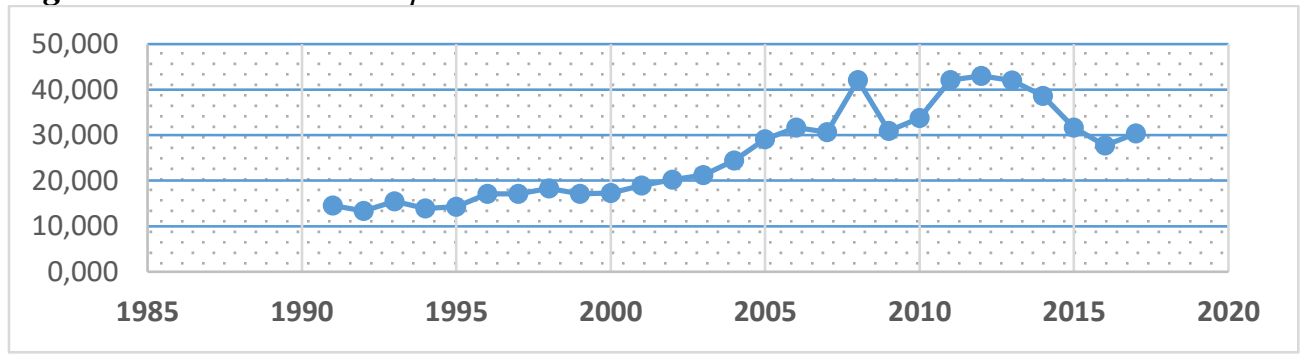

Source: Authors' calculation of data from unctad.org

However the Trade Openness indicators of India in comparison with the other world economies are still lower when compared with the world economies.

\section{Data and Model}

The study employs the Augmented Dickey Fuller (ADF) Test for unit root and Autoregressive Distributive Lag Model (ARDL) cointegration approach which entails the Wald Test, Long run OLS estimation test, Error Correction and short Run relationship estimation test, as well as the short run Causality test. The data on the variables of model and Trade Openness Indicator were sourced from the various data sources of The Handbook of Statistics on the Indian Economy and the UNCTAD, World Bank Databases. The Data for the index and the model is collected and analysed for the period of 1991 to 2017.

\subsection{Model Specification}

The research model is specified as follow:

$\mathrm{GDP}=\mathrm{f}(\mathrm{EX}, \mathrm{IM}, \mathrm{EXR}, \mathrm{DI}, \mathrm{INF})$ 
where: GDP- Real Gross Domestic Product.

IMP- Imports (Imports to GDP ratio)

EX- Exports (Exports to GDP ratio)

DI- Domestic Investment (Gross Domestic Capital Formation as a Ratio of GDP)

INF- Inflation

EXR-Exchange Rate

Hence the equation takes the form of:

$$
\mathrm{GDP}=\alpha+\beta 1 \mathrm{EX}+\beta 2 \mathrm{IMP}+\beta 3 \mathrm{EXR}+\beta 4 \mathrm{INF}+\beta 5 \mathrm{DI}+\mathrm{U}
$$

\section{Results}

An augmented Dickey-Fuller test (ADF) tests the null hypothesis that a unit root is present in a time series sample. Owing to the fact that the study uses a time series data and to avoid spurious regression, the series are first checked whether they are stationary or not. The alternative hypothesis is different depending on the kind of version the test is used, but is usually stationarity or trend-stationarity. The current study employed the ADF Unit Root Test with the results presented in Table 1.

Table 1. Results for Unit Root Test

\begin{tabular}{|l|l|l|l|l|l|l|l|}
\hline & \multicolumn{3}{|l|}{ Level } & \multicolumn{3}{l|}{ First Difference } & \\
\hline Variable & None & Intercept & $\begin{array}{l}\text { Int \& } \\
\text { Trend }\end{array}$ & None & Intercept & $\begin{array}{l}\text { Int \& } \\
\text { Trend }\end{array}$ & Order \\
\hline GDP & 13.59 & 7.60 & 1.37 & 1.96 & -1.89 & $-3.89^{*}$ & $\mathrm{I}(1)$ \\
\hline DI & 1.20 & -0.69 & $-5.19^{*}$ & - & - & - & $\mathrm{I}(0)$ \\
\hline EX & 3.81 & 2.04 & -1.22 & -3.86 & $-3.89^{*}$ & $-4.33^{*}$ & $\mathrm{I}(1)$ \\
\hline EXR & 2.64 & -0.57 & -1.45 & $-3.60^{*}$ & $-5.12^{*}$ & $-5.01^{*}$ & $\mathrm{I}(1)$ \\
\hline IMP & 2.38 & 0.86 & -1.19 & $-3.68^{*}$ & $-5.52^{*}$ & -3.22 & $\mathrm{I}(1)$ \\
\hline INF & -1.24 & $-3.38^{*}$ & $-3.61^{*}$ & - & - & - & $\mathrm{I}(0)$ \\
\hline
\end{tabular}

Note: HO: Unit root in series, $*$ which denotes rejecting $\mathrm{HO}$ at $5 \%$ level of significance.

Source: Authors' Calculation based on data collected from UNCTAD.

From the analysis of the above results, some variables are integrated of order one while some are integrated of order zero, i.e., I(O) and I (1). The study finds that the adoption of the ARDL cointegration technique does not require protests for unit roots unlike other techniques. Consequently, ARDL cointegration technique is preferable when dealing with variables that are integrated of different order, $\mathrm{I}(\mathrm{O})$ and $\mathrm{I}(1)$ or combination of the both and, robust when there is a single long run relationship between the underlying variables in a small sample size. From the results of the above Table 1, the best method of estimation to be employed for the study is chosen to be the Autoregressive Distributive Lag Model (ARDL) co-integration technique proposed by Pesaran (2001). The major advantage of this approach lies in its 
identification of the cointegrating vectors where there are multiple cointegrating vectors.

\subsection{The Autoregressive Distributive Lag Model (ARDL)}

The ARDL cointegration approach was developed by Pesaran and Shin (1999) and later by Pesaran et al. (2001). It has got three advantages in comparison with other previous and traditional cointegration methods that were in use. The first one is that the ARDL technique does not need that all the variables under study must be integrated of the same order and it can be applied when the under-lying variables are integrated of order one, order zero or fractionally integrated. The second advantage of the model is that the ARDL test is relatively more efficient in the case of small and finite sample sizes of data. The third advantage is that by applying the ARDL technique we can obtain unbiased estimates of the long-run model (Harris and Sollis, 2003). The ARDL model used in this study is expressed as follows:

$\Delta \mathrm{GDP}=\alpha+\beta 1$ GDP t- $1+\beta 2 \mathrm{EXt}-1+\beta 3$ IMPt- $1+\beta 4 \mathrm{EXRt}-1+\beta 5$ DIt- $1+\beta 6$ INFt- $1+$ $\Sigma \Theta i \Delta$ GDPt-i $+\Sigma \delta i \Delta$ EXt-i $+\Sigma$ Vi $\Delta$ IMPt-i $+\Sigma \phi i \Delta$ EXRt-i $+\Sigma \omega i \Delta$ DIt-i $+\Sigma$ pi $\Delta$ INFt-i + $\mathrm{Ut}$.

Where: $\beta \mathrm{i}$-denotes the Long run multipliers

$\alpha$ - Intercept

Ut- the Error term

$\Theta, \mho, \gamma, \phi, \omega, \beta-$ Short run dynamic coefficients.

\subsection{Bound Test}

The first test in the model of ARDL is the test for Cointegration. This test can be carried out using the Wald Test for testing the null hypothesis of no co-integration involved. The bound test is mainly based on the joint F-statistic which its asymptotic distribution is non-standard under the null hypothesis of no cointegration. The first step in the ARDL bounds approach is to estimate the equations by ordinary least squares (OLS). The estimation of the equations tests for the existence of a long-run relationship among the variables by conducting an F-test for the joint significance of the coefficients of the lagged levels of the variables. i.e. $\mathrm{H} 0: \beta 1=\beta 2=\beta 3=\beta 4=\beta 5=\beta 6=0$.

Table. 2 Bound Test Result

\begin{tabular}{|l|l|l|l|l|}
\hline Country & F-Statistic & Lag & Lower Bound & Upper Bound \\
\hline India & 3.987 & 2 & 2.29 & 3.78 \\
\hline
\end{tabular}

Source: Author' Calculation from the data compiled from UNCTAD.

\subsubsection{The Decision Rule: Reject HO if F-statistic falls outside the bounds}

The first level is calculated on the assumption that all variables included in the ARDL model are integrated of order zero, while the second one is calculated on the assumption that the variables are integrated of order one. The null hypothesis of no 
cointegration is rejected when the value of the test statistic exceeds the upper critical bounds value, while it is accepted if the F-statistic is lower than the lower bounds value. From the above test it is revealed that F-statistic falls out of the bounds; hence we reject the null hypotheses and conclude that the variables are cointegrated. Once cointegration is established, the conditional the ARDL approach is to determine the long-run co-efficient.

\subsection{The Long Run Relationship Estimation}

The estimated OLS coefficients of the long-run relationship between exchange rate and imports with GDP are found to be negative and significant. However, the relationship between exports and domestic investment with GDP was found to be positive and significant.

Table. 3 Long Run Relationship Estimation

\begin{tabular}{|l|l|l|l|}
\hline Variables & Coefficient & T-Statistic & Prob. \\
\hline EXR & -120.2569 & -1.322095 & 0.0028 \\
\hline EX & 25442.85 & 2.822454 & 0.0065 \\
\hline DI & 8115.610 & 10.15098 & 0.0000 \\
\hline IMP & -9296.114 & -1.010288 & 0.0658 \\
\hline INF & -21.30105 & -0.666078 & 0.4349 \\
\hline C & -1050.582 & -2.008848 & 0.0059 \\
\hline R-Squared & 0.90 & \\
\hline DW STAT & 1.90 & \multicolumn{3}{l|}{} \\
\hline F-STAT & 46.61 & \multicolumn{5}{l|}{} \\
\hline PROB & 0.00 &
\end{tabular}

Source: Authors' Calculation from the data compiled from UNCTAD.

The relationship between the variables of inflation and GDP is found to be negative, but insignificant. The R-squared value presents a high explanatory power of the independent variables and dependent variables, while the overall significance of the model as indicated by the F-statistic presents the significance of the model. LM serial correlation test indicates the absence of the serial correlation and the CUSUM test in Appendix 1 shows the stability of the model. The long run relationship results thus confirm to the Mercantilist ideology of the economic theory that promotes exports and discourages imports. The results of the empirical works are also in line with the findings of the work of Atioyebi (2012) and Zahoor (2012).

\subsection{Short Run Relationship Estimation}

After the estimation of the Long run coefficients, the next step involves in the ARDL approach is the analysis of Error Correction and estimation of short run coefficients. The results of the analysis were presented in Table 4: 
Table 4. Error Correction Representation

\begin{tabular}{|c|c|c|c|}
\hline Variables & Co-efficient & T-Statistic & Prob. \\
\hline $\mathrm{C}$ & -65.86643 & -0.540 & 0.426 \\
\hline $\mathrm{D}(\mathrm{GDP}(-1))$ & -0.001723 & -0.005 & 0.886 \\
\hline $\mathrm{D}(\mathrm{EX})$ & 32248.03 & 3.241 & 0.005 \\
\hline $\mathrm{D}(\mathrm{EX}(-1))$ & 13114.26 & 0.961 & 0.336 \\
\hline $\mathrm{D}(\mathrm{EX}(-2))$ & 5211.194 & 0.307 & 0.580 \\
\hline D(IMP) & -7532.093 & -0.922 & 0.362 \\
\hline $\mathrm{D}(\mathrm{IMP}(-1))$ & 771.7678 & 0.100 & 0.821 \\
\hline $\mathrm{D}(\mathrm{IMP}(-2))$ & -1412.566 & -0.212 & 0.723 \\
\hline $\mathrm{D}(\mathrm{EXR})$ & -72.32827 & -1.003 & 0.322 \\
\hline $\mathrm{D}(\operatorname{EXR}(-1))$ & 27.40140 & 0.313 & 0.686 \\
\hline $\mathrm{D}(\mathrm{DI})$ & 12456.28 & 2.416 & 0.024 \\
\hline $\mathrm{D}(\mathrm{DI}(-1))$ & -1873.851 & -0.276 & 0.684 \\
\hline $\mathrm{D}(\mathrm{INF})$ & -36.37052 & -0.887 & 0.331 \\
\hline $\mathrm{D}(\mathrm{INF}(-1))$ & -66.15924 & -1.732 & 0.104 \\
\hline ECT(-1) & -0.813301 & -2.377 & 0.031 \\
\hline $\mathrm{C}$ & -65.86652 & -0.620 & 0.426 \\
\hline R-SQUARED & 0.76 & & \\
\hline F- STAT. & 5.39 & & \\
\hline PROB. & 0.00 & & \\
\hline
\end{tabular}

Source: Authors' Calculation from the data compiled from UNCTAD.

The established long term relationship is further confirmed by the significant Error correction Term (ECT). The coefficient of the ECT presents the speed of the adjustment i.e. following a shock 81 percent adjustment towards the long run equilibrium is completed in one year. The short run relationship result reveals a positive and significant relationship between exports and domestic investment with the GDP. The relationship between the variables imports, exchange rate and inflation with GDP was found to be negative and insignificant. The R-squared value presents a high explanatory power of the independent variables, the F-statistics as well presents an overall significance of the model. LM serial correlation test presents the absence of autocorrelation and the application of the CUSUM test too presents the stability of the model.

\subsection{Short Run Causality}

Causality testing is used to analyse the dynamic relationship between the time series data. It attempts to depict whether or not a time series is useful in forecasting the another. The study employs the Wald test to determine the short run causality between the variables.

From the results above, there exists a short run causality running from export, exchange rate and domestic investment to the GDP. However, the table presents that there is no short run causality between the imports and inflation to the GDP (Table 5): 
Table. 5 Short Run Causality Result

Note: *denotes reject $\mathrm{HO}$.

\begin{tabular}{|l|l|l|}
\hline Variable & F-statistic & Prob. \\
\hline Ex & 3.75 & $0.02^{*}$ \\
\hline IM & 0.51 & 0.57 \\
\hline EXR & 6.32 & $0.01^{*}$ \\
\hline DI & 3.32 & $0.02^{*}$ \\
\hline INF & 0.97 & 0.33 \\
\hline
\end{tabular}

Source: Authors' Calculation from the data compiled from UNCTAD.

\section{Conclusions and Policy Recommendations}

The study is also in line with the empirical literatures of scholars in this area. Azees et al. (2014), Zahoor et al. (2012) and Atoyebi et al. (2012) stated that international trade accelerates growth. Indian economy adopted the liberalization regime during 90s, which accelerated the growth of international trade. The recent initiatives of the government- Make in India, Export Promotion Strategies, Start up Initiatives and promotion of Brand India are in the right direction to promote the exports of the country. In particular, further enhancement of the production of more exportable commodities with tax incentives and export promotion subsidies are necessary for accelerating GDP growth, along with these the government also needs to lower the export tariff in order to encourage more exports as this is one more variable which has a positive impact on growth.

The government should also try to discourage imports as this has an important negative bearing of economic growth except that of capital goods that can used as intermediaries and raw material stage. The government can do this by imposing strict restrictions such as quotas and increase in import tariffs because importation has a negative effect on the economic growth of India. Recently, the stregthening of the exchange rate of Rupee is a worrisome issue. Measures need to be taken to keep the rupee value stable and government needs to encourage domestic investments into the economy through enhancement of gross capital formation as it boosts the economic growth of the country.

At last international trade has been the engine of growth but the negative effects of trade cannot be ignored as given by the theories of immersing growth (Bhagavati, 1958; Johnson 1955) this needs must be managed by policy implementation to lower the ill effects of trade on the domestic economy. A study which includes this option would make an interesting addition to the current work.

\section{References:}

Atoyebi, et al. 2012. Foreign Trade and Economic Growth in Nigeria: An Empirical Analysis. American Academic and Scholarly Research Journal, 4(5). 
Azeez, et al. 2014. Effect of International Trade on Nigerian Economic Growth: The 21st Century Experience. Journal of Economics, Commerce and Management, 11(10).

Bhagavati J., Desai, P. 1970. Planning for industrialization (Industrialization and trade policies since 1951). Oxford University press, London, Parts I, II, 131-111 and 213477.

Balassa, B. 1978. Exports and Economic Growth. Journal of Development Economics, (5), 181-189.

Gairuzazmi, M.G. 2011. The Impact of Trade Liberalization on the Economic Performance of OIC Member Countries. Journal of Economic Cooperation and Development, 32(1), 1-18.

Kravis, I.B. 1970. Trade as a Handmaiden of Growth: Similarities between the $19^{\text {th }}$ and $20^{\text {th }}$ Century. Economic Journal, 850-870.

Jayati, G. 2006. Trade Liberalization and Economic Restructuring: Can India Skip the Industrial Phase? IDEAS Conference, Muttukadu, 27-29 January.

Marshall, A. 1938. Principles of Economics. London.

Robertso, D.H. 1938. The Future of the International Trade. Economic Journal, (48), 14.

Nurske, R. 1961. Patterns of Trade and Development, Stockholm. 1959 in Equilibrium and Growth in the World Economy. Harvard University Press, 241-281.

Pesaran, et al. 2001. Bound Testing Approaches to the Analysis of Level Relationships. Journal of Applied Econometrics, (16), 289-326.

Samuelson, P.A. 1973. Economics, McGraw Hill, Koga Kusha Limited, New York.

Shreesh, B., Kishore, K. 2012. Impact of International Liberation on the Indian Economy. Journal of Emerging Knowledge on Emerging Markets, 4(5).

Maizel, S.A. 1968. The effects of industrialization on export. John Wiley \& Sons Inc., NY.

Themberge, J.D. 1968. Economics of Trade and Development. John Wiley \& Sons, Inc, NY.

UNCTAD. 2010. How are the Poor Affected by International Trade in India: An Empirical Approach. UNCTAD report 2010.

Yemi, B. 2014. Effects of International Trade on Nigerian Economic Growth: An Unpublished Thesis. Ibadan.

Zahoor, et al. 2012. Effects of International Trade on Economic Growth: The Case Study of Pakistan. International Journal of Academic Research in Progressive Education and Development, 1(2).

\section{APPENDIX:}

Appendix Table 1

Growth Rate of India's Exports, Imports \& GDP

\begin{tabular}{|c|c|c|c|c|c|}
\hline Year & Exports & Imports & GDP & Year & TOI \\
\hline 1991 & -1.348 & -13.282 & 1.057 & 1991 & 14.594 \\
\hline 1992 & 10.722 & 15.311 & 5.482 & 1992 & 13.352 \\
\hline 1993 & 9.905 & -3.351 & 4.751 & 1993 & 15.481 \\
\hline 1994 & 15.994 & 17.791 & 6.659 & 1994 & 13.874 \\
\hline 1995 & 22.413 & 29.297 & 7.574 & 1995 & 14.293 \\
\hline 1996 & 8.081 & 9.322 & 7.550 & 1996 & 17.083 \\
\hline 1997 & 5.748 & 9.197 & 4.050 & 1997 & 17.108 \\
\hline 1998 & -4.488 & 3.736 & 6.184 & 1998 & 18.290 \\
\hline 1999 & 6.668 & 9.305 & 8.846 & 1999 & 17.151 \\
\hline 2000 & 18.820 & 9.672 & 3.841 & 2000 & 17.339 \\
\hline 2001 & 2.316 & -2.195 & 4.824 & 2001 & 18.981 \\
\hline 2002 & 13.581 & 12.155 & 3.804 & 2002 & 20.193 \\
\hline 2003 & 19.722 & 28.382 & 7.860 & 2003 & 21.269 \\
\hline
\end{tabular}

Appendix Table 2

Trade Openness Inde 


\begin{tabular}{|l|c|c|c|c|c|}
2004 & 29.995 & 37.512 & 7.923 & 2004 & 24.449 \\
\hline 2005 & 29.965 & 43.192 & 7.923 & 2005 & 29.067 \\
\hline 2006 & 22.277 & 24.876 & 8.061 & 2006 & 31.631 \\
\hline 2007 & 23.275 & 28.563 & 7.661 & 2007 & 30.639 \\
\hline 2008 & 29.748 & 39.962 & 3.087 & 2008 & 42.142 \\
\hline 2009 & -15.357 & -19.883 & 7.862 & 2009 & 30.915 \\
\hline 2010 & 37.259 & 36.170 & 8.498 & 2010 & 33.749 \\
\hline 2011 & 33.821 & 32.615 & 5.241 & 2011 & 42.094 \\
\hline 2012 & -2.006 & 5.433 & 5.456 & 2012 & 43.024 \\
\hline 2013 & 6.071 & -4.962 & 6.386 & 2013 & 42.011 \\
\hline 2014 & 2.492 & -0.534 & 7.410 & 2014 & 38.630 \\
\hline 2015 & -16.964 & -14.858 & 7.996 & 2015 & 31.622 \\
\hline 2016 & -1.272 & -8.242 & 8.170 & 2016 & 27.715 \\
\hline 2017 & 13.117 & 24.409 & 7.168 & 2017 & 30.378 \\
\hline 2018 & 8.534 & 14.344 & 6.982 & & \\
\hline
\end{tabular}

Source: Authors' Calculation based on data collected from UNCTAD. 